\title{
Environment tolerance of Cunninghamia konishii Hayata in northern of Vietnam
}

\author{
Mai Phuong Pham* \\ Vietnam - Russia Tropical Centre, 63 Nguyen Van Huyen, Cau Giay, Ha Noi, Vietnam
}

\begin{abstract}
Cunninghamia konishii Hayata is one of the rarest timber trees in Vietnam, that have a high scientific and commercial value for timber and essential oil. According to the IUCN, the species is treated as Endangered (EN)-A2cd; B2ab (ii, iii, v) (IUCN), and Near Threatened (VU) - A1a, d, c1 according to Vietnam Red Data Book. We conducted research on the environment tolerance of the this species to determine the key climatic, soil, and topographic threshold that limits species occurrence in order to find scientific basis for ecosystem management. A survey in northern Vietnam was implemented to determine the natural distribution and damage to $C$. konishii by human interactions, and local cultivation. Fourteen socialenvironmental factors were investigated within five committee authorities focus group discussions (FGDs) from the document of questionnaire completed by nine commune heads. The result showed the highest sustainable index (SI) was focused in the Que Phong (A3), Ky Son (A1), communes. This suggests that SI was related to soil erosion $\left(\mathrm{F}_{1}\right)$.
\end{abstract}

\section{Introduction}

Environmental tolerance of a species is a key factor in the area of distribution, and is a result of the evolutionary process and environmental adaptations [1-2]. A theory for expression of a population's response to density-independent gradients of environmental factors is derived for the case of asexuality, the potential utility of this methodology for the analysis of standard data for environmental assessment [3]. The physiological limitations of a species are directly influenced by environmental conditions, however species also influenced by human activity. Environmental variables and social status interact in complex ways to influence species occurrence, in their survival and reproduction rates [1].

Cunninghamia konishii Hayata, known in Vietnam, under its vernacular name Sa Moc Dau, Sa Mu Dau, May Lung Linh, and May Lang Lenh [4-5], belongs to Cupressaceae family found in north and central Taiwan, China (Fujian), north of Laos and Vietnam (Son La, Ha Giang, Thanh Hoa, Nghe An province). C. konishii is light, aromatic, and strong timber that have high commercial value. According to the IUCN (2013), the species is treated as Endangered (EN)-A2cd; B2ab (ii, iii, v) [6], or Near Threatened (VU) - A1a, d, c1 according to Vietnam Red Data Book [7]. Almost all populations of C. konshii are protected in nature

*Corresponding author: phamphuong911vh@gmail.com 
forest reserves, but the species still under threats of extinction due to rural development and agriculture land expansion. The largest population of the species distributed is in the East of Nghe An, a province of Vietnam, because of low human contact due to high mountain range.

This species has limited number of individuals and a small population in the nature [812]. C. konishii species are scattered in small clusters, mixed with evergreen primary forest growth within monsoon tropical climate that have average annual temperature of $13-19^{\circ} \mathrm{C}$, rainfall level over $1,500 \mathrm{~mm}$, on weathered soil from granite or other silicate rocks at an altitude of $960-2,000 \mathrm{~m}$ above sea level [13-15].

Resource management methods using GIS are widely used as GIS is capable of handling extremely large amounts of data and diverse information. In the Nature Reserve management database, information on species distribution is important data, specially for the threatened fauna and flora species. Furthermore, application AHP method by GIS was used to determine the importance and influence of individual ecological factors on the species based on expert knowledge [16-19]. Study of species distribution can help to improve population of wild trees [20-21]. Biological records of wild species based on the species distribution within the indicated area described their environmental variables. In addition, the ranges and limits of environmental tolerance of this species was untouched by research on small areas. Therefore, the objective of the present work is to unveil the limits of $C$. konishii distribution in Vietnam, as well as identify its climatic, soil and topographic tolerance limits. Status of sustainability also was determined using the AHP (analytic hierarchy process), a multi-criteria decision analysis is instrumental to evaluate the influence of social- environmental factors to the species sustainable index. The data provide a basis for scientific suggestions for development of C. konishii in Vietnam provinces. The results of this publication are just the first step for further deep advanced studies for entire ecoregion.

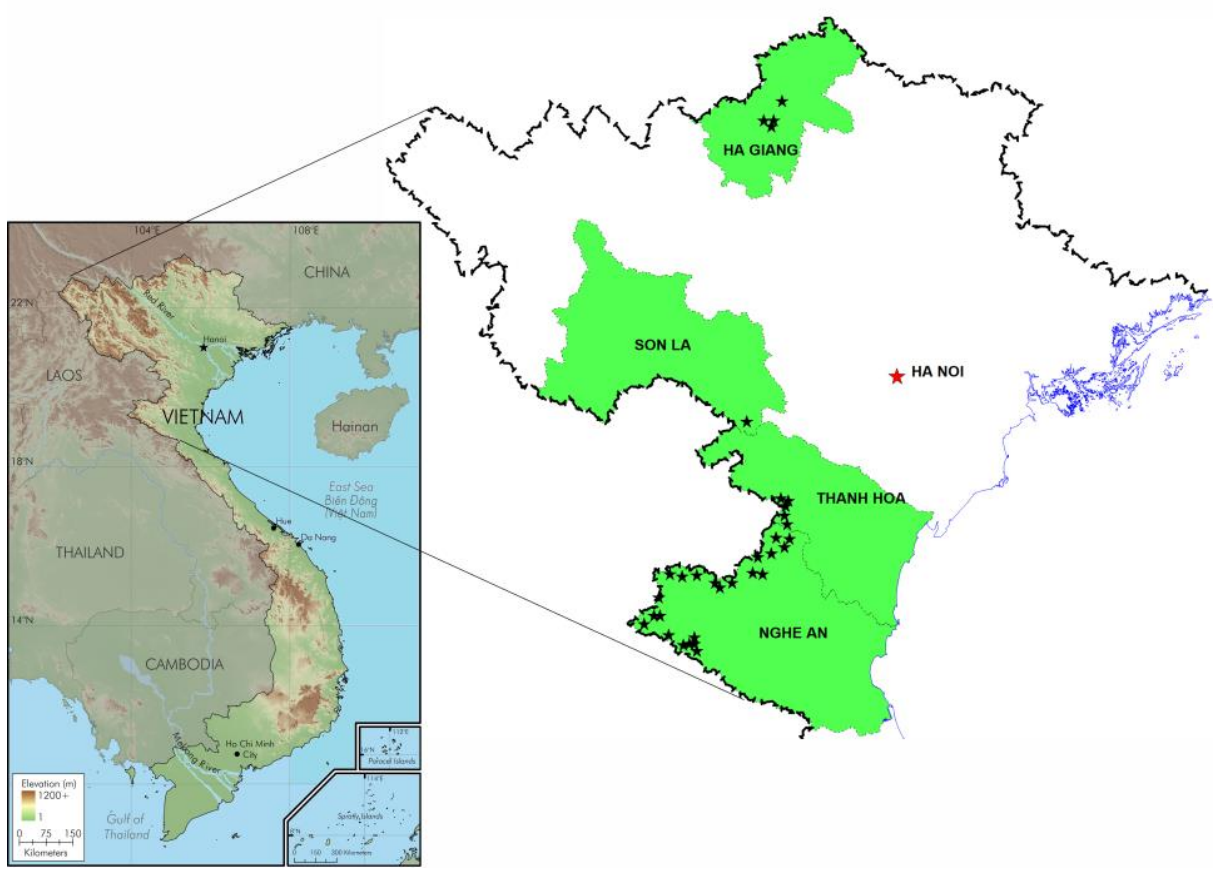

Fig 1. Location of study area and C. konishii population in Vietnam 


\section{Materials and methods}

\subsection{Data collection}

We used the linear survey method, combined with a coordinate locator (GPS) to determine the position of C. konishii trees (Fig.1). We also used horizontal survey method to determine the cover of the forest canopy [22]. In addition, we studied soil properties as implemented by Thimo et al. [23]. We investigated and interview directly forest rangers, forest owners and local people to collect information of the species occurrence. Climatic data were obtained via WorldClim (1950-2000) at a spatial resolution of 5 arc-minutes $(\sim 10 \mathrm{~km})$ [24]. Data on altitudes were gathered from a global digital elevation model at a spatial resolution of 5 arcminutes $(\sim 10 \mathrm{~km})$. Topographic variables were obtained by dowload DEM on SRTM web site (http://srtm.csi.cgiar.org). Slope and aspect from the DEM data were derived by using ArcGIS 10.0. The distance to river layer extracted from the National river and stream map (https://www.bandovn.vn/). Land use data was retrieved from survey. Tree cover collected from Global Forest Watch database (http://globalforestwatch.org).

To describe the environmental variables that $C$. konishii can tolerate in Vietnam and therefore that determine their habitat, species occurrences (longitude and latitude) were imported to Geography Information System (GIS). Therefore, environmental variables of each population distribution were showed by overlay of composite map of environmental variables. The results were analyzed for Means, maximum (largest value), minimum (smallest value) over a number of values were calculated by SPSS v20.

\subsection{AHP technique}

AHP uses a basic 9-point scale to represent importance of factors $\left(\mathrm{F}_{\mathrm{i}}\right)$ according to expert assessment (table 1) [25-26], $n$ was the 14 factors involved in the process (Table 5). Some C. konishii experts (9 commune heads in Ky Son, Con Cuong, Que Phong, Tuong Duong, Quy Chau, Muong Lat, Thuong Xuan, Hoang Su Phi, Moc Chau communes of Song Hinh district of Phu Yen province) were invited to fill a pairwise comparison table of the factors investigated during field survey to evaluation the level of importance of the factors and relations between them. The matrix format in pair comparison is described as follows:

$$
A=\left[\begin{array}{ccccc}
a_{11} & a_{12} & \cdots & \cdots & a_{1 n} \\
a_{21} & a_{22} & \cdots & \cdots & a_{2 n} \\
\vdots & \vdots & \cdots & \cdots & \vdots \\
\vdots & \vdots & \cdots & \cdots & \vdots \\
a_{n 1} & a_{n 2} & \cdots & \cdots & a_{n n}
\end{array}\right]
$$

Where: $a_{i j}$ : the elements in the weight matrix, w: the weight; $a_{i i}=1$ và $a_{i j}=1 / a_{j i}$. The results form a vector of weights: $W=\left[\mathrm{w}_{1}, \mathrm{w}_{2}, \mathrm{w}_{3}, \ldots, \mathrm{w}_{\mathrm{n}}\right] . \mathrm{a}_{\mathrm{ij}}$ is calculated based on Saaty's eigenvector method. The eigenvector is normalized by equation (2) and then the weights are calculated using equation (3).

$$
\begin{gathered}
a_{i j}=\frac{a_{i j}}{\sum_{j=\mathbf{1}}^{n} a_{i j}} \quad i, j=1,2,3 \ldots . n \\
w_{i j}=\frac{\sum_{j=\mathbf{1}}^{n} a_{i j}}{n} \quad i, j=1,2,3 \ldots . n
\end{gathered}
$$


Table 1. The Fundamental scale for pairwise comparisons

\begin{tabular}{cl}
\hline $\begin{array}{c}\text { Intensity of } \\
\text { importance }\end{array}$ & \multicolumn{1}{c}{ Judgments of verbal attribute labels } \\
\hline 9 & Absolute importance \\
7 & Very strongly importance or preferred \\
5 & Strong importance or strongly preferred \\
3 & Weak importance, moderately important or preferred \\
$2,4,6,8$ & Intermediate values between adjacent judgments the two \\
1 & Equally preferred more important or preferred \\
\hline
\end{tabular}

Source: Saaty, 2008

With the AHP algorithm, weights are calculated according to the standardized method of the matrix following the steps: (1) Sum the each column value of the pair comparison matrix; (2) Divide each component in the pair comparison matrix with the corresponding column total (the result is normalized by the pair comparison matrix); (3) Sum each row of the normalized matrix; (4) Divide the sum of each row by the sum of all rows given the corresponding weighted set for the factor. The final, the weight of factors for evaluation from experts through statistical analysis in Microsoft Excel 2016. The weighting accuracy was verified by the consistency ratio (CR) according to the formula (4):

$$
\mathrm{CR}=\frac{\mathrm{CI}}{\mathrm{RI}}
$$

In which: CI: consistency index, which measures the degree of consistent deviation, determined by formula (5):

$$
\mathrm{CI}=\frac{\lambda_{\max }-\mathrm{n}}{\mathrm{n}-1}
$$

$\lambda_{\max }$ is the mean value of the consistent vector and $\mathrm{n}$ is the number of criteria.

$$
\lambda_{\max }=\frac{1}{n} \cdot\left(\frac{\sum_{j=1}^{n} a_{1 j} \cdot w_{11}}{w_{11}}+\frac{\sum_{j=1}^{n} a_{2 j} \cdot w_{22}}{w_{22}}+\ldots+\frac{\sum_{j=1}^{n} a_{n j} \cdot w_{n n}}{w_{n n}}\right)
$$

$\mathrm{RI}$ is a random index, or mean value of CI, depending on the number of indicators to be compared (Table 2).

Table 2. RI value according to different indicators

\begin{tabular}{cccccccccccccccc}
\hline $\mathbf{n}$ & $\mathbf{1}$ & $\mathbf{2}$ & $\mathbf{3}$ & $\mathbf{4}$ & $\mathbf{5}$ & $\mathbf{6}$ & $\mathbf{7}$ & $\mathbf{8}$ & $\mathbf{9}$ & $\mathbf{1 0}$ & $\mathbf{1 1}$ & $\mathbf{1 2}$ & $\mathbf{1 3}$ & $\mathbf{1 4}$ & $\mathbf{1 5}$ \\
$\boldsymbol{R I}$ & 0 & 0 & 0.52 & 0.89 & 1.11 & 1.25 & 1.35 & 1.4 & 1.45 & 1.49 & 1.52 & 1.54 & 1.56 & 1.58 & 1.59 \\
\hline
\end{tabular}

In the AHP, the CR shows the level of consistency among the expert's opinions during discussion. If $\mathrm{CR}$ is less than $<0.1$ or $10 \%$ (less than $0.1 \%$ to $10 \%$ ) this proves that the correlation matrix between selected ecological factors is threatened as reliable [27-31]. Therefore, the weights of the factors influencing the sustainable of the species are accepted to add in the GIS layers to calculate the sustainable index (CI) for C. konishii in the study area. 


\subsection{Multi-criteria decision analysis instrument}

Score for each factor $i$ on Table 5 was $\left(X_{i}\right)$ on each commune unit was determined base on the interview commune leader, the importance of factor $i$ are converted to factor weights $\left(W_{i}\right)$, $i$ rang from 1 to $m$, where $m$ was the total number of factor involved in the process. The weighted linear combination of $\left(W_{i}\right)$ and $\left(X_{i}\right)$ give sustainable index (SI) for each commune unit. Score of each level variable computed for each sustainable unit. These values are combined with the above mentioned overall weight to provide value for each sustainable unit. This process applying using the formula in $\mathrm{Eq}(7)$.

$$
S I=\sum_{i=1}^{m}\left(W_{i} \cdot X_{i}\right)
$$

\section{Results and Discussion}

\subsection{Searching for C. konishii occurrences}

Previous studies were analised for identification of natural distribution of $C$. konishii in Vietnam [4, 12, 32]. Special survey was also implemented in August-November of 2020, the species was recorded as indicated in Table 3.

Table 3. Location of C. konishii distribution

\begin{tabular}{|c|c|c|c|c|}
\hline Province & District & Commune & $\begin{array}{c}\text { Elevation } \\
(\mathbf{m})\end{array}$ & Number of individuals \\
\hline \multirow{24}{*}{ Nghe An } & \multirow{6}{*}{ Ky Sơn (A $\left.\mathbf{A}_{1}\right)$} & Na Ngoi & $1637-1908$ & 280 \\
\hline & & Tay Son & 1900 & 65 \\
\hline & & Muong Tip & 1556 & 5 \\
\hline & & Muong Ai & 2000 & 2 \\
\hline & & My Ly & $1500-2000$ & undefined \\
\hline & & Nam Can & $2000-2500$ & 2 \\
\hline & \multirow{3}{*}{ Con Cuong ( $\left.\mathbf{A}_{2}\right)$} & Chau Khe & $800-1000$ & 120 \\
\hline & & Mon Son & $800-1000$ & undefined \\
\hline & & Lang Khê & $800-1000$ & undefined \\
\hline & \multirow{6}{*}{ Que Phong (A3) } & Hanh Dich & $1500-2000$ & 222 \\
\hline & & Thong Thu & $1300-1800$ & 5 \\
\hline & & Nam Giai & $1300-1700$ & 50 \\
\hline & & Hanh Dich & $1300-1800$ & 970 \\
\hline & & Tri Le & $1200-1800$ & 40 \\
\hline & & Quang Phong & $1060-1185$ & 4 \\
\hline & \multirow{5}{*}{ Tương Duong (A4) } & Tam Hop & $65-75$ & 2 \\
\hline & & Tam Quang & $65-80$ & undefined \\
\hline & & Nhon Mai & & 1 \\
\hline & & Mai Son & N.a & undefined \\
\hline & & Nga My & 100 & $\begin{array}{l}\text { undefined } \\
\text { undefined }\end{array}$ \\
\hline & \multirow{4}{*}{ Quy Chau (As) } & & 200 & undefined \\
\hline & & Chau Hoan & $100-200$ & undefined \\
\hline & & & $100-200$ & undefined \\
\hline & & Dien Lam & 1237 & undefined \\
\hline \multirow{2}{*}{ Thanh Hoa } & Muong Lat (A6) & $\mathrm{Pu} \mathrm{Hu}$ & $700-1200$ & 2 \\
\hline & Thuong Xuan $\left(\mathbf{A}_{7}\right)$ & Bat Mot & $1300-1400$ & 31 \\
\hline Ha Giang & Hoang Su Phi (As) & Tung San & 1212 & 2 \\
\hline Son La & Moc Châu (A9) & Chieng Xuan & $1500-1600$ & 1 \\
\hline
\end{tabular}




\subsection{Environmental tolerance}

A environment tolerance is the ranger of conditions within which the species can live and its degree of abundance to conditions within the scope of the natural environmental condition (Table 4).

Table 4. Environmental variables

\begin{tabular}{|c|c|c|c|c|c|c|c|}
\hline $\begin{array}{c}\text { Variabl } \\
\text { es }\end{array}$ & $\begin{array}{l}\text { Environment } \\
\text { al predictors } \\
\end{array}$ & Code & Unit & Data type & Min & Max & Mean \\
\hline \multirow{4}{*}{$\begin{array}{l}\text { Topogra } \\
\text { phy }\end{array}$} & Aspect & Topo 1 & Degree & Continuous & 0 & 360 & 45 \\
\hline & Slope & Topo2 & Degree & Continuous & 20 & 50 & 45 \\
\hline & Elevation & Topo3 & meter & Continuous & 950 & 2500 & 1500 \\
\hline & $\begin{array}{l}\text { Distance to } \\
\text { river }\end{array}$ & Topo4 & meter & Continuous & 100 & 1000 & 100 \\
\hline \multirow{4}{*}{ Soil } & Soil type & SOIL & & Categorical & \multicolumn{3}{|c|}{$\begin{array}{c}\text { Ferralic Acrisols; } \\
\text { Humic Acrisols }\end{array}$} \\
\hline & $\mathrm{pH}$ & $\mathrm{pH}$ & & Continuous & 5 & 5.5 & 5.2 \\
\hline & $\mathrm{N}_{\text {total }}$ & $\mathrm{N}$ & $\%$ & Continuous & 0.2 & 0.27 & 0.25 \\
\hline & Humidity & Humi & $\%$ & Continuous & 1.5 & 3 & 1.7 \\
\hline \multirow[b]{2}{*}{$\begin{array}{l}\text { Land } \\
\text { use }\end{array}$} & Forest cover & Cover & Percent & Continuous & 80 & 100 & \\
\hline & Land use type & Land & & Categorical & \multicolumn{3}{|c|}{$\begin{array}{c}\text { Protect forest } \\
\text { (Evergreen broad } \\
\text { leaved mixed forest) }\end{array}$} \\
\hline \multirow{7}{*}{ Climate } & $\begin{array}{l}\text { Annual Mean } \\
\text { Temperature }\end{array}$ & $\mathrm{C} 1$ & $\begin{array}{l}\text { Celsius } \\
\text { degree }\end{array}$ & Continuous & $\begin{array}{c}11.4 \\
4\end{array}$ & 24.63 & 20 \\
\hline & $\begin{array}{l}\text { Mean Diurnal } \\
\text { Temperature } \\
\text { Range }\end{array}$ & $\mathrm{C} 2$ & $\begin{array}{l}\text { Celsius } \\
\text { degree }\end{array}$ & Continuous & 5.3 & 9.55 & 7 \\
\hline & $\begin{array}{l}\text { Temperature } \\
\text { Seasonality }\end{array}$ & $\mathrm{C} 3$ & & Continuous & $\begin{array}{c}285 . \\
32\end{array}$ & $\begin{array}{c}501.4 \\
7\end{array}$ & 400 \\
\hline & $\begin{array}{l}\text { Temperature } \\
\text { Annual Range }\end{array}$ & $\mathrm{C} 4$ & $\begin{array}{l}\text { Celsius } \\
\text { degree }\end{array}$ & Continuous & 16.4 & 21.1 & 18 \\
\hline & $\begin{array}{l}\text { Annual } \\
\text { Precipitation }\end{array}$ & $\mathrm{C} 5$ & Millimeter & Continuous & $\begin{array}{c}117 \\
8\end{array}$ & 2335 & 2000 \\
\hline & $\begin{array}{l}\text { Precipitation } \\
\text { of the Driest } \\
\text { Month }\end{array}$ & C6 & Millimeter & Continuous & 0 & 9 & 7 \\
\hline & $\begin{array}{l}\text { Precipitation } \\
\text { Seasonality }\end{array}$ & C7 & & Continuous & $\begin{array}{c}78.2 \\
7 \\
\end{array}$ & $\begin{array}{c}107.1 \\
8 \\
\end{array}$ & 93 \\
\hline
\end{tabular}

The topography variables reveal that the level of tolerance to elevations were above 1000 $\mathrm{m}$, while tolerance to slopes were above 25 degrees, tolerance to aspect were from $0-50$ degree of northeast. The tolerance to distance to river also reveals that species optimum is above $1 \mathrm{~km}$ of distance. In agreement with data presented by other researchers, species are found from $1.000-1.500 \mathrm{~m}$, slope from $15-45$ [8-15]. Fig 2 was a representation of $C$. konishii population's common distribution for most influencing environmental factors, no individuals were recorded with value outside this range. 

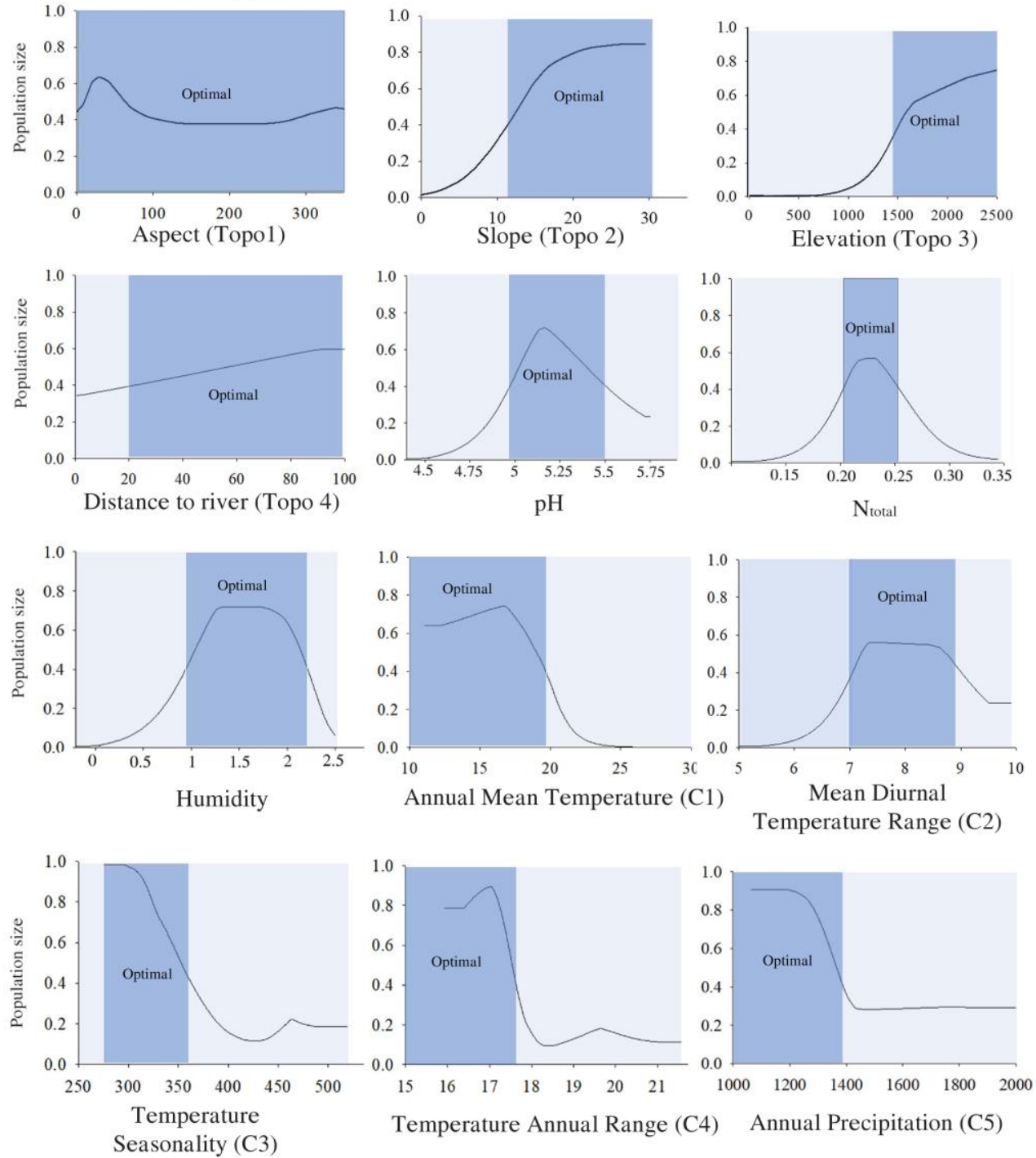

Temperature Annual Range (C4) Annual Precipitation (C5)

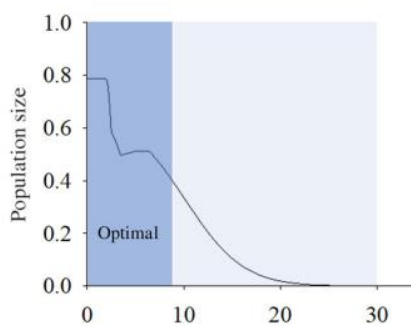

Precipitation of the Driest Month (C6)

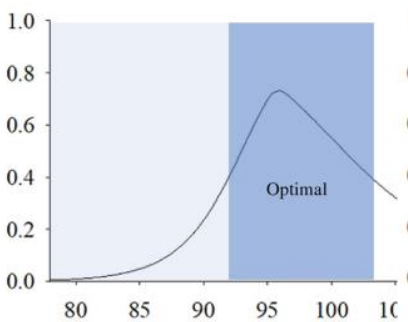

Precipitation Seasonality (C7)

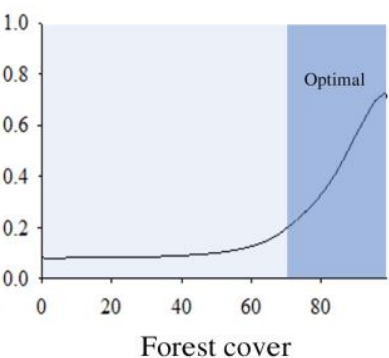

Forest cover

Fig 2. Optimal zone of environmental variables for C. konishii 


\subsection{Factors influencing to the area of $C$. konishii population in Vietnam}

Analysis of the environmental performance of land use is the part of the content of environmental impact assessments for land use options. Environmental efficiency analysis is an important content to ensure the sustainable development of the land use type [33]. This study aimed to assess the environmental efficiency on commune units with agriculture land use. The impact of such land use on the environment included both two groups of factors: direct impact on the environment in the study area and indirect impact on the environment outside the study area (Table 5). However, it also effects on species population was thought that existed in the watershed of protected forests which agricultural activities are located around.

The table 5 comprise factor $\mathrm{F}_{\mathrm{i}}$ from $\mathrm{F}_{1}$ to $\mathrm{F}_{14}(m=14)$ were discovered from focus group discussions (FGDs) based on the Instruction for land evaluation TCVN 8409:2012 that was regulation of Ministry of Science and Technology of Vietnam [33]. Category of environmental impact assessments were divided on 3 category (Unsustainable, Less sustainable, Sustainable) correspond to score $(X: 1,2,3)$. The document of questionnaire to weight $(W)$ the importance of each factors were completed by 9 commune heads in Ky Son, Con Cuong, Que Phong, Tuong Duong, Quy Chau, Muong Lat, Thuong Xuan, Hoang Su Phi, Moc Chau communes of Song Hinh district, Phu Yen province, Vietnam.

Table 5. Category of environmental impact assessments

\begin{tabular}{|c|c|c|c|}
\hline Factors & Level & Category & $\begin{array}{c}\text { Score } \\
(X)\end{array}$ \\
\hline \multirow{3}{*}{$\mathbf{F}_{1}$ : Soil erosion } & Strong erosion & Unsustainable & 1 \\
\hline & Moderate erosion & Less sustainable & 2 \\
\hline & Weak erosion & Sustainable & 3 \\
\hline \multirow{3}{*}{$\mathbf{F}_{2}$ : Productivity of the land } & High production capacity & Unsustainable & 1 \\
\hline & Average production capacity & Less sustainable & 2 \\
\hline & Low production capacity & Sustainable & 3 \\
\hline \multirow{3}{*}{$\begin{array}{l}\text { F3: Flow characteristics in } \\
\text { streams }\end{array}$} & Overflow after rain & Unsustainable & 1 \\
\hline & Drought in the summer & Less sustainable & 2 \\
\hline & Flowing steadily & Sustainable & 3 \\
\hline \multirow{3}{*}{$\begin{array}{l}\text { F }_{4} \text { : The occurrence of } \\
\text { flooding and drought }\end{array}$} & Usually happens & Unsustainable & 1 \\
\hline & Medium occurrence & Less sustainable & 2 \\
\hline & Less happening & Sustainable & 3 \\
\hline \multirow{3}{*}{ F5: Water quality } & Poor quality (turbidity, polluted) & Unsustainable & 1 \\
\hline & Average quality & Less sustainable & 2 \\
\hline & Good quality (clean, no pollution) & Sustainable & 3 \\
\hline \multirow{3}{*}{$\begin{array}{l}\text { F6: Number and area of }_{\text {protection forest area }} \\
\text { proto }\end{array}$} & $\begin{array}{l}\text { Bad condition (deforestation, forest } \\
\text { fire) }\end{array}$ & Unsustainable & 1 \\
\hline & Average condition & Less sustainable & 2 \\
\hline & The forest is intact & Sustainable & 3 \\
\hline \multirow{3}{*}{ F7: Forest tree species } & Few species & Unsustainable & 1 \\
\hline & $\begin{array}{l}\text { Average number of species } \\
\text { (commercial crops) }\end{array}$ & Less sustainable & 2 \\
\hline & Multi-species, multi-layer & Sustainable & 3 \\
\hline \multirow{3}{*}{ F8: Wild animals } & Few species & Unsustainable & 1 \\
\hline & Moderate species & Less sustainable & 2 \\
\hline & Species diversity & Sustainable & 3 \\
\hline \multirow{4}{*}{$\begin{array}{l}\text { F9: Mining and hunting } \\
\text { methods }\end{array}$} & Destruction & Unsustainable & 1 \\
\hline & Selectively & Less sustainable & 2 \\
\hline & Protection & Sustainable & 3 \\
\hline & Mainly rain water & Unsustainable & 1 \\
\hline
\end{tabular}




\begin{tabular}{|c|c|c|c|}
\hline $\begin{array}{l}\mathbf{F}_{10} \text { : Water sources for } \\
\text { agriculture }\end{array}$ & $\begin{array}{l}\text { Rain water is essential and with } \\
\text { additional irrigation } \\
\text { Big dam, deep well }\end{array}$ & $\begin{array}{c}\text { Less sustainable } \\
\text { Sustainable } \\
\end{array}$ & 3 \\
\hline \multirow{3}{*}{ F $_{11}$ : Control weeds and pests } & Use chemicals & Unsustainable & 1 \\
\hline & $\begin{array}{l}\text { Using mechanical and mechanical } \\
\text { methods }\end{array}$ & Less sustainable & 2 \\
\hline & $\begin{array}{c}\text { Biology, crop structure and } \\
\text { management }\end{array}$ & Sustainable & 3 \\
\hline \multirow{3}{*}{ 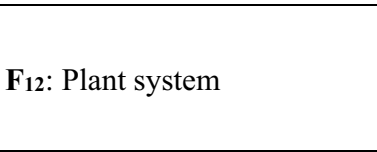 } & $\begin{array}{c}\text { Single culture farming, market- } \\
\text { orienteted }\end{array}$ & Unsustainable & 1 \\
\hline & Many species on repeat crops & Less sustainable & 2 \\
\hline & Crop rotation and polyculture & Sustainable & 3 \\
\hline \multirow{3}{*}{ F13: Labor } & Out of the community & Unsustainable & 1 \\
\hline & Family, cooperative & Less sustainable & 2 \\
\hline & Family and community hire & Sustainable & 3 \\
\hline \multirow{3}{*}{ F $_{14}$ : Financial resources } & External sources & Unsustainable & 1 \\
\hline & Family, cooperative & Less sustainable & 2 \\
\hline & $\begin{array}{l}\text { Credit institutions (cooperatives, } \\
\text { private enterprises, families) }\end{array}$ & Sustainable & 3 \\
\hline
\end{tabular}

Recently, assessment of the factors affected on the land use become more popular, especially there was instruction for production land evaluation that was implemented for all type of land use for agricultural production. The forest is a place strongly affected by human activities, so when the agricultural, forestry activities and economic development are not stable, it will lead to the risks of forest destruction. At that time, species populations are therefore affected through habitat loss or soil habitat degradation, erosion, flora and fauna loss. Results of the questionnaire have clarified exact important factors affecting the environment tolerance of the species population through the assessment of the sustainability of the local agricultural and forestry land. Soil erosion $\left(\mathrm{F}_{1}\right)$ was the top ranking of 14 factors involved in process with the weight was $21.1 \%$, followed by $\left(\mathrm{F}_{7}: 7.22 \%\right)\left(\mathrm{F}_{8}: 6.75 \%\right),\left(\mathrm{F}_{5}\right.$ : $6.23 \%),\left(\mathrm{F}_{13}: 5.59 \%\right),\left(\mathrm{F}_{9}: 4.99 \%\right)$. Consistency CR was: 0.02 , this shows the reliability of the questionnaire results. Sustainable index (SI) showed that the highest SI was concentrated in the Que Phong $\left(\mathrm{A}_{3}\right)$, Ky Son $\left(\mathrm{A}_{1}\right)$, followed by Con Cuong $\left(\mathrm{A}_{2}\right)$, Tuong Duong $\left(\mathrm{A}_{4}\right)$, Quy Chau $\left(\mathrm{A}_{5}\right)$, Muong Lat $\left(\mathrm{A}_{6}\right)$, Thuong Xuan $\left(\mathrm{A}_{7}\right)$, Hoang Su Phi $\left(\mathrm{A}_{8}\right)$, Moc Chau $\left(\mathrm{A}_{9}\right)$ communes of Song Hinh district of Phu Yen province. This suggests that high SI is related to population size $\left(A_{3}\right.$ and $A_{1}$ were the area found the large number of individual species) and soil erosion $\left(F_{1}\right)$ that considered as an indicator for sustainable management of agricultural land resources in the buffer zones around reserves or protected forest.

\section{Conclusions}

The environmental tolerance of a $C$. konishii determined to a great extent its area of distribution for the expression of a population's response to density-independent gradients of environmental factors. The physiological limitations of species are directly influenced by environmental conditions, their occurrences also reflect the variability of many of these environmental parameters. Our survey was implemented in all locations where the species were recorded on previous researches, thesis, report, internet source, publications and interviews. Therefore, we are confident that this result is quite complete for surveying the distribution of species in Vietnam. The environmental data collected was determined by Geography Information System (GIS) through hundreds of of species populations localities recorded. Twenty environmental tolerance factors have been established. The results show that species adapt to cold climate on high mountains, high temperature amplitude, and small amount of raining. On the other hand, FGDs with the participation of commune leaders was 
implemented. Soil erosion $\left(F_{1}\right)$ was important factor affecting the environment tolerance of the species population through the assessment of the sustainability of the local agricultural area (buffer zones around reserves or protected forest), followed by forest tree species $\left(\mathrm{F}_{7}\right)$, wild animals $\left(\mathrm{F}_{8}\right)$, water quality $\left(\mathrm{F}_{5}\right)$. Que Phong $\left(\mathrm{A}_{3}\right)$, Ky Son $\left(\mathrm{A}_{1}\right)$ were indicated high sustainable index than other alternatives.

We are grateful to Institute of Tropical Ecology of Vietnam - Russia Tropical Centre. We appreciate an administration of Pu Hoat Nature Reserve - Nghe An province, Xuan Lien Nature Reserve - Thanh Hoa province, Xuan Nha Nature Reserve - Son La province, Hoang Su Phi protected forest - Ha Giang province for their support of the research. Special thanks to Mr Nguyen Van Sinh, Mr Nguyen Van Manh, Mr Vi Van Tinh who have been working as forest managers at Pu Hoat Nature Reserve and many local people at Hanh Dich commune for their support of our survey. Thanks to E. Sterling (New York) and K. Koy (Berkeley) for the map used in Fig 1.

A survey was supported by the project "Application of geographic information method (GIS) and molecular biology for investigation, monitoring and development Cunninghamia konishii Hayata species of Vietnam" from Vietnam - Russia Tropical Centre, Ha Noi, Vietnam for 2020-2022 years.

\section{Reference}

1. J.J. Wiens, C.H. Graham, Annu Rev Ecol Evol S, 36, 519-539 (2005)

2. E. A. Grigorieva, A. B. Sukhoveeva, Geo env sust, 13(1), 92-98 (2020)

3. M. Lynch, W. Gabriel, Am Nat, 129(2), 283-303 (1987)

4. N.T.T. Nga, N.A. Dung, N.T. Chung, T.H. Thai, N.D. Hung, Eng Appl Sci Res, 43, 121-124 (2016)

5. L.V Averyanov, T.H. Nguyen, S.K. Nguyen, T.V. Pham, L. Vichith, B. Somchanh, L. Shengvilai, K.L. Phan, L. Soulivanh, C. Khamfa, Nordic J Bot, 32(6), 765-805 (2014)

6. P. Thomas, Y. Yang, The IUCN red list of threatened species (2013)

7. M.O.S.T, V.A.S.T, Vietnam red data book, part II. Plants. Natural Sciences and Technology Publishing House (2007)

8. S.Y. Lu, C.I Peng, Y.P. Cheng, K.H. Hong, T.Y. Chiang, Genome, 44(5), 797-807 (2001)

9. V.S. Nguyen, Report collection on the 3rd Conference on Ecology and Biological Resources, 746-751 (2009) (Vietnamese)

10. T.P.T. Nguyen, M.T. Nguyen, K.L. Phan, K.L. Phan, J Biotechnol, 7(1), 85-92 (2009) (Vietnamese)

11. T.P.T. Nguyen, Thesis Ph.D, Institute of Ecology and Biological Resources (Vietnam Academy of Science and Technology ,2012) (Vietnamese)

12. P.K. Loc, P.V. The, N.S. Khang, L.V. Averyanov, J Econ Ecol, 45, 33-45 (2013) (Vietnamese)

13. N.T. Hiep, P.K. Loc, N.D.T. Luu, P.I. Thomas, A. Farjon, L. Averyanov, J. Regalado, Vietnam conifers: Conservation status review 2004. Fauna \& Flora International, Vietnam Programme, Hanoi, 55-56 (2004) (Vietnamese)

14. N.M.Tam, N.T. Hoa, N.T.P. Trang, J Biotechnol, 31(2), 66-72 (2009) (Vietnamese)

15. N.T.T. Nga, N.V. Hieu, M.A. Sim, N.A. Dung, T.H. Thai, Bio J, 39(1), 122-128 (2017)

16. H.V. Chuong, Hue Univer J Sci, 50, pp. 5-16 (2009) (Vietnamese) 
17. V.V. Hao, Application of AHP and GIS to evaluate the suitability of Pinus merkusii and Acacia auriculiformis in Cu Kuin district, Dak Lak province, Tay Nguyen University of Forestry (2009) (Vietnamese)

18. H.V. Chuong, P.G. Tung, N.B. Ngoc, Hue Univer J Sci, 6, 17-28 (2012) (Vietnamese)

19. P.M. Phuong, Landscape geography in the XXI century, 84-88 (2018)

20. J. Ehrlén, W.F. Morris (2015), Eco letters, 18, 303-314 (2015)

21. J. Bosch, I. Iglesias, M.J. Muñoz, A. Torre, Emerg Dis, 64, 1720-1733 (2016)

22. P. W. Richards, The tropical rain forest: an ecological study (Cambridge, 1957)

23. K. Thimo, M. Anika, V. Doris, S. Janina, T. Manfred, V.S. Nguyen, M.H. Nguyen, V.C Ho, M. Leonardo, V. Sylvia, V.B. Jesus, J. Reinhold, Basic App Eco, 16, 665-673 (2015)

24. R.J. Hijmans, S.E. Cameron, J.L. Parra, P.G. Jones, A. Jarvis, (2005). Inter J Clima, 25(15), 1965-1978 (2005)

25. T.L. Saaty, The analytical hierarchy process, (McGraw Hill, New York, 1980)

26. T.L. Saaty, Fundamentals of decision making and priority theory with the analytic hierarchy process (RWS Publications, Pittsburg, 2000)

27. N.D.K. Dayawansa, G.K. Ekanayake, Land suitability identification for a production forest through GIS techniques. Forestry and Biodiversity, Map India Conference, India (2003)

28. O. Dengiz, C. Gol, F.E. Sario Lu, S. Edi, African J Agricul Res, 5(12), 1482-1496 (2010)

29. D. Draper, A. Rosselló-Graell, C. Garcia, C.T. Gomes, C. Sérgio, Biological Conser, 113(3), 337-349 (2003)

30. J.R. Olarieta, G. Besga, R. Rodríguez-Ochoa, A. Aizpurua, A. Usón, Soil Use Manag, 22(3), 238-244 (2006)

31. C. Perpina, J.C. Martinez-Llario, A. Navarro, Land Use Policy, 31, 326-335 (2013)

32. K.L. Phan, L. Phan, J. Regalado, L. Averyanov, B. Maslin, Pak J Bot, 49(5), 2037-2068 (2017)

33. M.S.T.V, TCVN 8409:2012. Assessment of environmental impacts of land use types in Vietnamese conditions (2012) 